NASA Technical Memorandum 105638

\title{
$992 / 2$
}

\section{Progress in the Development of}

$\therefore \quad=$ Lightweight Nickel Electrode

Doris L. Britton

Lewis Research Center

Cleveland, Ohio

Prepared for the

35th International Power Sources Symposium

sponsored by the Institute of Electrical and Electronics Engineers

Industry Application Society

Cherry Hill, New Jersey, June 22-25, 1992 
significant decrease in total capacity of the Fibrex nickel electrode was observed with long term cycling but rather a decrease in the high rate discharge capacity (refs. 2 to 5). The Fibrex nickel electrode also has an advantage over the SOA nickel electrode due to its pore size distribution. The shift to smaller pores and increase in the volume requirements of the SOA electrode during cycling will result in the electrode having a greater affinity for the electrolyte. This effect can dry the separator and will lead to a high separator resistance. This traditional increase in small pores of the cycled SOA nickel electrode is not found in the Fibrex electrode. In addition to a two-fold increase in volume of the micropores of the cycled Fibrex electrode, the volume of the larger pores (over $9 \mu \mathrm{m}$ ) increases two to four times as shown in figure 1 (refs. 3 to 5). This pore size distribution of the Fibrex nickel electrode should improve the electrolyte management of the $\mathrm{Ni}-\mathrm{H}_{2}$ cell. It has been noted that electrolyte management can have a significant effect on the cycle life and performance of the $\mathrm{Ni}-\mathrm{H}_{2}$ cell and should be one of the prime considerations in the overall design of the cell (ref. 6).

\section{CELL DESCRIPTION}

To verify the performance of lightweight nickel electrodes in boilerplate hardware, a $\mathrm{Ni}-\mathrm{H}_{2}$ cell using a Fibrex nickel electrode was assembled at NASA Lewis. The cycle test was conducted using a boilerplate cell with a 5- by $5-\mathrm{cm}$ active area. A sample of the cell components is shown in figure 2 . It consists of a stack of nickel electrodes, separator, hydrogen electrode, and gas screen. The nickel electrode is made from an 80-mil thick, 90-percent porous Fibrex plaque loaded to $1.6 \mathrm{~g} / \mathrm{cm}^{3}$ void volume. The separator consists of three layers of 6-mil-thick beater-treated asbestos. The hydrogen electrode was made by Life Systems Incorporated which consists of a mixture of platinum and Teflon applied to a gold plated nickel screen. The gas screen, located behind the hydrogen electrode, is 60 -mil-thick nickel Exmet which was compressed to 40 mil to fit into the cavity designed for the hydrogen electrode and gas screen. An electrolyte reservoir plate (ERP), which is incorporated into the cell, is made of 125 -mil-thick foam metal. The current collectors are gold plated nickel. A graphic representation of the unit cell cross section is shown in figure 3. The components are assembled in a stack, as shown in figure 4. After assembly, the entire stack is vacuum-filled with 26-percent $\mathrm{KOH}$ electrolyte. The $\mathrm{KOH}$ electrolyte is allowed to stand in the stack overnight, then the excess electrolyte is drained out. The stack is placed in the pressure vessel. The test chamber is evacuated and filled with hydrogen to $3.4 \mathrm{~atm}$ (50 psi). The chamber is then connected to the test facility as shown in figure 5 . The test facility consists of independent cell test positions. Each test position consists of a charge/discharge controller, a dc power supply and an ampere-hour meter. A Modicon 884 programmable controller controls the timing for the cycle tests. The data acquisition system is handled by an Escort 2 system developed at NASA Lewis. Current, voltage, and the time are recorded for each cell. The Escort 2 system scans the data every $18 \mathrm{sec}$. The charge and discharge ampere-hours and watt-hours are calculated from current and time on every scan. The pressure is measured using a strain gauge located on the cell dome. The charge-to-discharge ratio (ampere-hours in on charge to ampere-hours out on discharge) is calculated from the capacities. Every $60 \mathrm{sec}$, the data is saved and stored to a data collector. The data can be retrieved for data and graphical output.

\section{CELL TESTING}

The general procedure for testing the $\mathrm{Ni}-\mathrm{H}_{2}$ boilerplate cell, using Fibrex nickel electrode, consists of initial characterization testing; continuous 90-min life cycle testing; final characterization testing; and failure analysis. 


\section{Initial Characterization Testing}

Initial characterization testing of the $\mathrm{Ni}-\mathrm{H}_{2}$ cell, conducted before the life cycle test, consists of capacity measurements at various charge and discharge rates to evaluate the effects of these rates on the cell capacity. For the charge rate effect, the cell is charged at $\mathrm{C} / 10$ rate for $18 \mathrm{hr}, \mathrm{C} / 2$ rate for $160 \mathrm{~min}$, or $\mathrm{C}$ rate for $80 \mathrm{~min}$, respectively, followed by discharge at $\mathrm{C} / 2$ to $0.5 \mathrm{~V}$. For the discharge rate effects, the cell is charged at $\mathrm{C} / 2$ rate for $160 \mathrm{~min}$ followed by discharge at $\mathrm{C} / 5, \mathrm{C} / 2, \mathrm{C}$, or $1.37 \mathrm{C}$ rates, respectively, to $0.5 \mathrm{~V}$.

\section{Continuous Cycle Testing}

After the initial characterization test, the boilerplate cell is life cycle tested using a 90-min cycle regime at 40 -percent DOD. The continuous test regime consists of charging to a constant $0.48 \mathrm{C}$ rate for 55 min immediately followed by discharge at a constant $0.69 \mathrm{C}$ rate for $35 \mathrm{~min}$. Cell capacities are measured, every 1000 cycles, by charging at the $\mathrm{C}$ rate for 80 min followed by discharging at the $0.69 \mathrm{C}$ rate to $0.5 \mathrm{~V}$. Failure of the cell will occur when the discharge voltage degrades to $0.5 \mathrm{~V}$ during the course of the constant current 35 -min discharge at the $0.69 \mathrm{C}$ rate.

Initial results of the lightweight $\mathrm{Ni}-\mathrm{H}_{2}$ cell testing are very encouraging. The cell has been cycling for over 8000 cycles, as shown in figure 6 , with an acceptable performance. Utilization is calculated by using the ratio of the measured capacity to the theoretical capacity. The effect of cycling on the end of charge and discharge voltages for the lightweight $\mathrm{Ni}-\mathrm{H}_{2}$ are shown in figure 7 . An average end-of-discharge voltage of about $1.16 \mathrm{~V}$ is observed for the first 1000 cycles. The average end of discharge voltage dropped to about $1.10 \mathrm{~V}$ after 7000 cycles. The end of charge voltage remained stable at about $1.54 \mathrm{~V}$. The cycle testing will continue until the end of discharge voltage reaches $0.5 \mathrm{~V}$.

\section{Final Characterization Testing}

Final characterization testing will be conducted after the cell fails. Capacity measurements, similar to initial characterization testing, will be performed. Results of the cycled and uncycled cell capacity, measured at different rates, will be compared.

\section{Failure Analysis}

Post-test cell teardown and failure analysis will be conducted to evaluate the cause for failure. Failure analysis will consist of the following:

(1) Visual inspection of the stack components (e.g., electrodes and electrolyte);

(2) Flooded capacity measurements of the uncycled and cycled Fibrex electrode;

(3) Weight loss and electrode expansion of the cycled electrodes;

(4) Pore size distribution of the uncycled and cycled electrode using the mercury intrusion porosimeter method;

(5) Electrolyte distribution between the nickel electrode, hydrogen electrode, and separator;

(6) Scanning electron micrographs. 


\section{CONCLUSION}

The development and cycle life testing of the Fibrex nickel electrode has demonstrated the feasibility of an improved nickel electrode giving a higher specific energy $\mathrm{Ni}-\mathrm{H}_{2}$ cell. Studies indicate a 48 -percent improvement in weight for the fibrous nickel electrode over the SOA sintered electrode.

From these investigations, it can be concluded that the Fibrex nickel electrode is an attractive electrode candidate for a lightweight $\mathrm{Ni}-\mathrm{H}_{2}$ cell. Early cycle life testing of a $\mathrm{Ni}-\mathrm{H}_{2}$ cell using an 80-mil-thick, 90-percent porous Fibrex nickel electrode has shown promising results when cycled at 40 -percent DOD. To date, over 8000 cycles have been accumulated.

\section{REFERENCES}

1. Colucci, S.L.: System for Stretch Casting Filamentary Shaped Bodies. U.S. Patent 4,312,670, 1982.

2. Britton, D.L.: Electrochemical Impregnation and Cycle Life of Lightweight Nickel Electrodes for NickelHydrogen Cells. Proceedings of the 34th International Power Sources Symposium, IEEE, New York, pp. 235-238, 1990 (also, NASA TM-103140, 1990).

3. Britton, D.L.: Performance of Lightweight Nickel Electrodes. International Power Sources Symposium, 33rd; Proceedings, Electrochemical Soc., Inc., Pennington, NJ, pp. 467-445, 1988 (also, NASA TM-100958, 1988).

4. Britton, D.L.: Lightweight Fibrous Nickel Electrodes for Nickel-Hydrogen Batteries. NASA TM-101997, 1989.

5. Britton, D.L.: Characterization and Cycle Tests of Lightweight Nickel Electrodes. Proceedings of the Symposium on Nickel Hydroxide Electrodes, The Electrochemical Society, Inc., Pennington, NJ, pp. 233-246, 1990 (also, NASA TM-102399, 1989).

6. Thaller, L.H.; Manzo, M.A.; and Sanabria, O.D.: Design Principles for Nickel-Hydrogen Cells and Batteries. Intersociety Energy Conversion Engineering Conference (IECEC), 20th; Proceedings, Vol. 1, SAE, Warrendale, PA, pp. 1.145 - 1.150, 1985 (also, NASA TM-87037, 1985).

TABLE I.-CALCULATED SPECIFIC ENERGY OF A 48-AH NICKEL-

HYDROGEN ĊELLL USING NICKEL ELECTRODES WITH

DIFFERENT THICKNESSES, POROSITIES,

AND LOADING LEVELS

\begin{tabular}{|l|c|c|c|c|c|}
\hline & Thickness & Porosity & $\begin{array}{c}\text { Loading } \\
\text { level }\end{array}$ & $\begin{array}{c}\text { Specific } \\
\text { energy }\end{array}$ & $\begin{array}{c}\text { Relative } \\
\text { specific } \\
\text { energy }\end{array}$ \\
\hline SOA & 30 & 85 & 1.6 & 56.56 & 1.00 \\
& 30 & 85 & 1.8 & 60.49 & 1.07 \\
& & & & & 1.09 \\
& 30 & 85 & 1.6 & 61.44 & 1.17 \\
& 30 & 90 & 1.6 & 66.40 & 1.21 \\
& 30 & 90 & 1.8 & 68.29 & 1.20 \\
& 30 & 93 & 1.6 & 67.73 & 1.29 \\
& 30 & 93 & 1.8 & 73.06 & 1.36 \\
& 80 & 90 & 1.6 & 76.72 & 1.48 \\
\hline
\end{tabular}



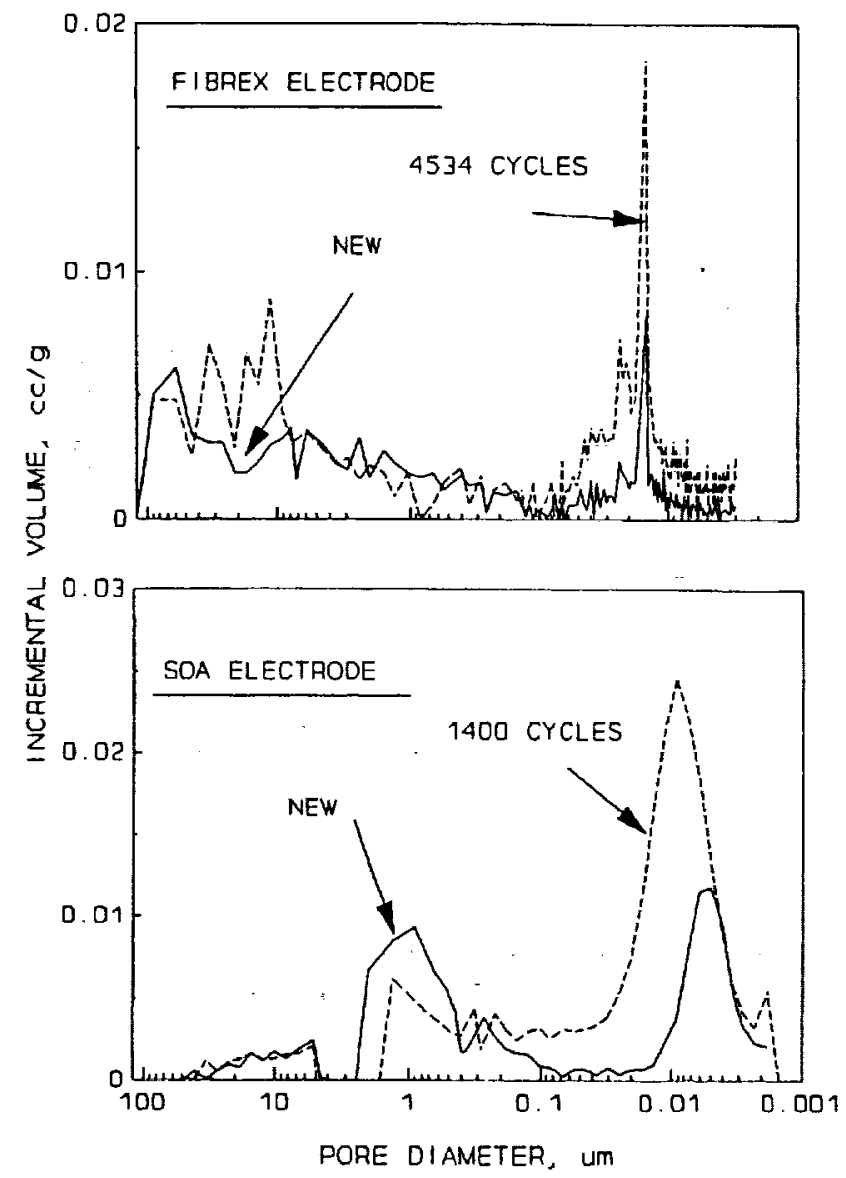

Figure 1.-Pore size distribution curves of Fibrex and SOA nickel electrodes.

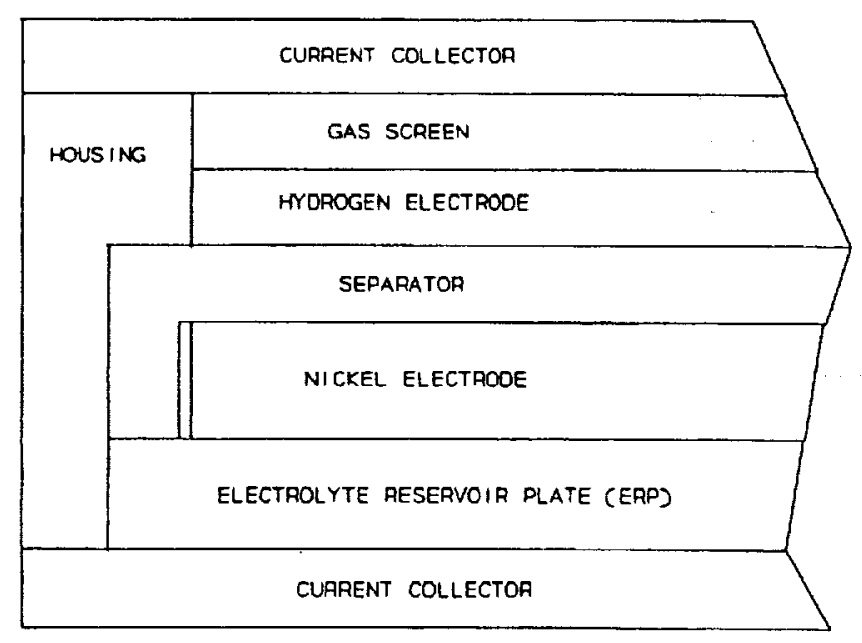

Figure 3.- Cross-sectional unit of the nickel-hydrogen cell.

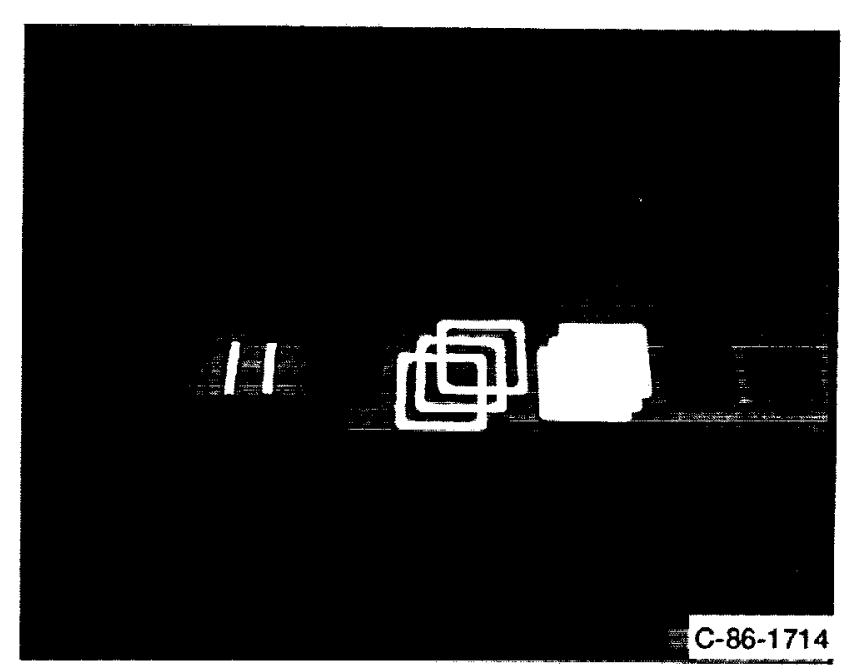

Figure 2.- Components of the nickel-hydrogen cell.

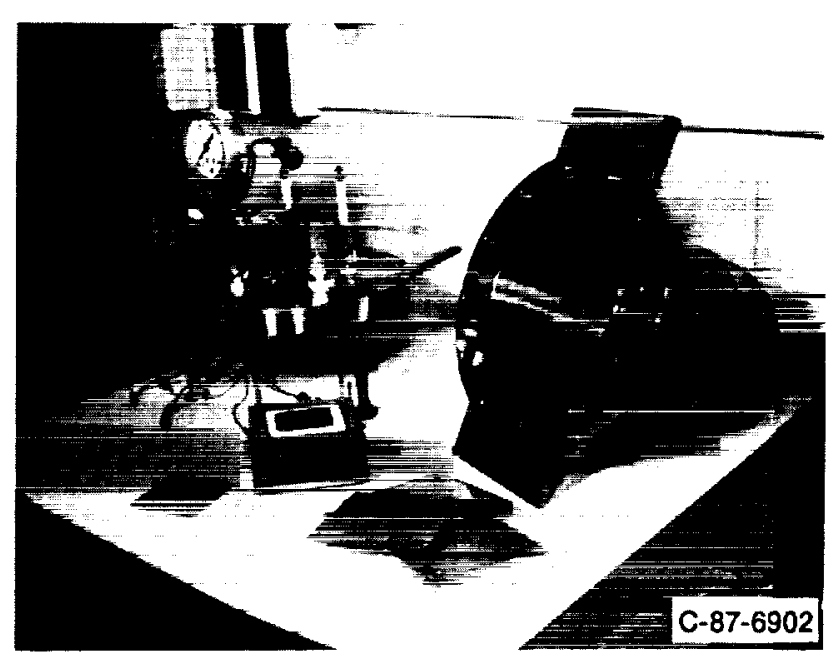

Figure 4.- Components of the nickel-hydrogen cell assembled in a stack with the pressure vessel. 


\author{
ORIGINAL PAGE \\ BLACK AND WHITE PHOTOGRAPH
}

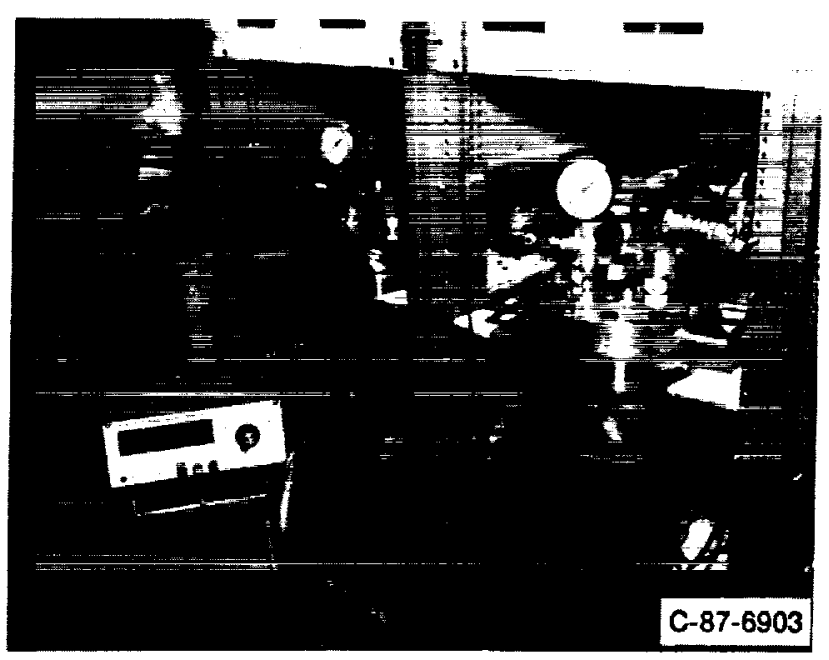

Figure 5.- Nickel-hydrogen cell test facility.

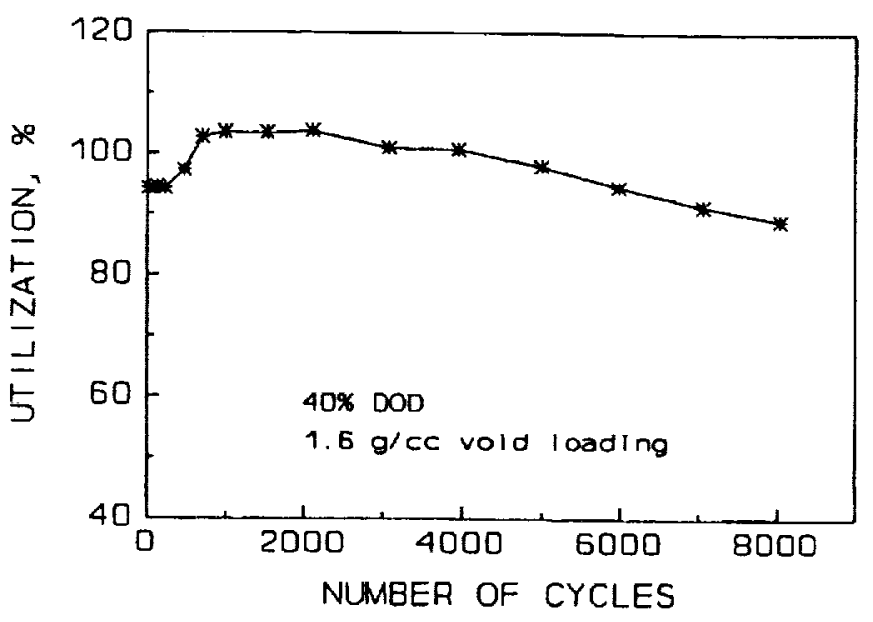

Flgure 6.- Utilization versus number of cycles of a nickelhydrogen cell using a Flbrex nickel electrode.

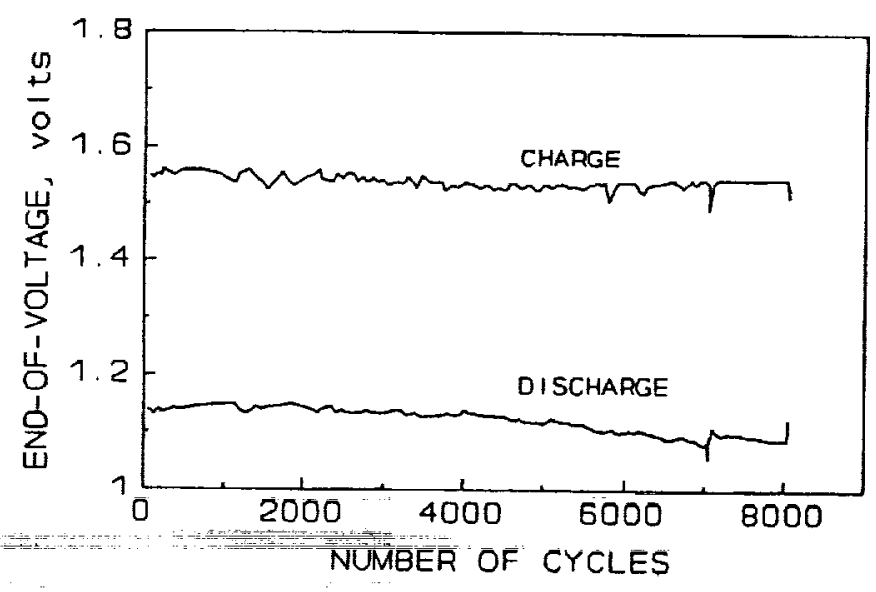

Figure 7.- End of charge and discharge voltages versus number of cycles for nickel-hydrogen cell using a Fibrex nickel electrode. 


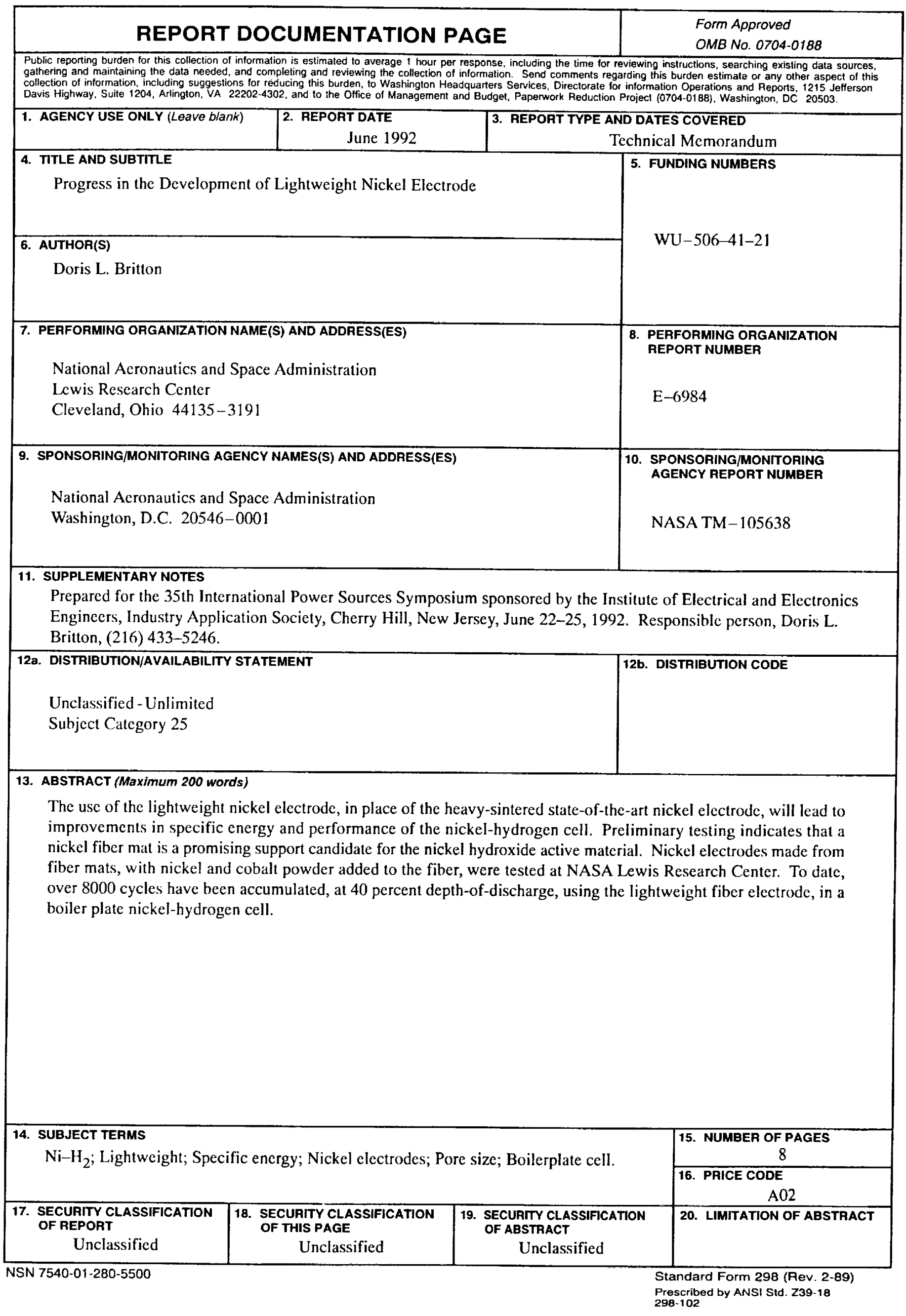


